\title{
EFFECT OF SOILLESS CULTURE SYSTEMS, NUTRIENT SOLUTIONS ON THE PRODUCTION AND QUALITY OF TWO HEAD LETTUCE CULTIVARS IN ROOF TOP FARMING
}

(Received: 5.4.2018)

\author{
By \\ Shreen S. F. El-Sayed \\ Vegetable Crops Department, Faculty of Agriculture, Cairo University, Giza, Egypt
}

\begin{abstract}
An experiment was conducted on the rooftop of Vegetable Crops department building, Faculty of Agriculture, Cairo University, Giza, Egypt, during the winter seasons of 2016 and 2017. The study aimed to investigate the effect of two production systems, viz., deep flow technique (DFT) and box system with two nutrient solutions (mineral and organic solutions), for urban roof top farming, on plant growth, and quality of two cultivars of crisp head lettuce, namely, 'Chianti' and 'Big bell'. The characters under investigations were plant growth (plant fresh weight, head fresh weight and head diameter), yield, chlorophyll content, dry matter percentage in leaves, percentage of total soluble solids (TSS \%), total sugars, nutrients (N, P and K) and nitrate concentrations in leaves. It was clear that all the studied characters were higher by using box system, mineral solution as a fertilizer and 'Big Bell', as compared with DFT system, organic solution as a fertilizer and 'Chianti', respectively. Nevertheless, it is recommended to use 'Chianti' in DFT system with organic solution as a fertilizer for lettuce production in roof top farming, because it gave the least concentration of $\mathrm{NO}_{3}$ in the leaves with relatively good total yield.
\end{abstract}

Key words: lettuce, DFT, box system, mineral solution, organic solution, urban rooftop farming, plant growth, quality

\section{INTRODUCTION}

Recently, global food production faces more challenges. In future world population of 9.6 billion by 2050 , rising urbanization, decreasing arable land and climate change. Over $50 \%$ of the world population live in cities, the number will rise to $70 \%$ by 2030. Application of urban agriculture could increase global food production by developing new locations for cultivation (Eigenbrod and Gruda, 2015). The advantages of urban production are allowing production, marketing and consumption of locally grown food within urban areas (Reese, 2014), in addition to reducing wastes by generating less packaging and less cost for food transportation (Gawad, 2014).

Urban rooftop farming is a type of urban agriculture on roofs of buildings (Germain et al., 2008). Production of vegetable crops on roof tops can contribute to better nutrition and health for the community by providing locally grown, safe, fresh and healthy food. It can improve air quality, reduce temperature, resulting in energy saving for air-conditioning in a building.
Consequently, it contributes to mitigating the urban heat-island effect (Gupta and Mehta, 2017).

Vegetation established on roofs enables the population to take pleasure in new, green spaces that meet the need for relaxation and leisure (Germain et al., 2008). It gives job opportunities for people who need a regular source of income to help them in their dependency. Urban rooftop farming helps in ridding of trash stored on rooftops and removes places for rodents, snakes and various insects (Gawad, 2014).

A hydroponic roof top garden involves growing vegetables in artificial medium, or in water, with controlled nutrient minerals in solution. It is considered the lightest of all roof top gardens and can be constructed on top of any building. Hydroponic systems can produce similar amounts of food as soil gardens in approximately $1 / 5$ of the space (Foss et al., 2011). Additionally, this type of rooftop gardening can save up to $90 \%$ of water compered to traditional gardening, while maintaining high quality of yield (Putra 
and Yuliando, 2015). Vegetable crops grown hydroponically do not suffer from weeds, insects and diseases are minimized, or absent (Bañez and Manipon, 2000).

Lettuce (Lactuca sativa L.) is a vegetable commonly cultivated in the soil. It is a low calorie food and a source of vitamin A, vitamin $\mathrm{C}$ and folic acid. It also contains the anti-oxidant quercetin, believed to help prevent asthma and allergies by acting as a natural antihistamine (Sanders, 2015). Lettuce is a vegetable crop grown successfully in different hydroponic systems. Under hydroponics, the growth period of lettuce is short (Carandang et al., 2016), being harvested at 30 days after transplanting, compared to 45 days when it is grown in soil (Santos and Ocampo, 2005), and has a higher content of vitamins A, D and E and copper than those grown in soil (Carandang et al., 2016). The characteristics of the various materials used as substrate directly, and indirectly, affect plant development and production. The choice of substrate in a hydroponic system must meet the appropriate water and air proportions that plant needs (Roosta and Afsharipoor, 2012). Lettuce grown in nutrient film technique (NFT) system had a greater yield than that grown in gravel medium (Lennard and Leonard, 2006), or coconut fiber, and contained higher TSS $\%$ and chlorophyll, but accumulated more nitrates (Kowalczyk, 2016).

Sanyé-Mengual et al. (2015) reported that the best techniques of lettuce cultivation in rooftop garden farming were floating in the summer, with $65-85 \%$ less environmental impact $\mathrm{kg}^{-1}$ than nutrient film. Abul-Soud (2015) investigated the ability of using peat moss:perlite (50:50) and sand:vermicompost (80:20) as a substrate culture for lettuce production in rooftop gardens, and found that using sand + vermicompost in 81 pots had higher vegetative and yield characteristics and $\mathrm{N}, \mathrm{P}$ and $\mathrm{K}$ contents compared to peat + perlite in 61 pots.

Fertilizer source affects vegetable production and quality under field conditions (El-Sayed, 2017), and in a hydroponic system (El-Sayed $e t$ al., 2016 a, b). However, there is controversy concerning the use of conventional and organic production. In soil, in some cases, mineral nutrition produced higher plant weight, plant height, leaf length, leaf width, head diameter and nitrate content $\left(\mathrm{NO}_{3}\right)$ in lettuce, compared with compost (Lai et al., 2008; Hosseny and Ahmed, 2009). while there was better growth of lettuce fertilized with compost than with inorganic fertilizer. Leaf analysis indicated higher $\mathrm{N}$ and $\mathrm{Mg}$ concentrations for synthetic fertilizer and higher $\mathrm{N}$ and $\mathrm{K}$ for compost treatments (Reis et al., 2013). It was determined that recommended amounts of inorganic fertilizer, used for comparison, had shorter, narrower leaves, with shorter plants and lower nitrate than lettuce grown with organic fertilizers (Liu et al., 2014).

Under soilless culture conditions compost tea was used as a source of organic fertilizer (Welke, 2005; Abul-Soud et al., 2015; El-Sayed et al., 2016 a,b; Carandang et al., 2016). Compost tea is an infusion where compost is soaked in water for a period of time with the aim of transferring soluble organic matter, macroand micro-nutrients and beneficial microorganisms into solution (Ingham, 2005). Little work has been done to assess nutritional benefits of compost tea on plant growth. No aerated compost tea was as effective as inorganic fertilizer in promoting growth of strawberry plants (Hargreaves et al., 2009). Aerated compost tea increased strawberry yield as compared to the control (Welke, 2005). Use of synthetic nutrient solution in soilless culture increased strawberry vegetative growth, chlorophyll content and $\mathrm{N}, \mathrm{P}$, and $\mathrm{K}$ concentrations in the leaves (El-Sayed et al. 2016 a,b; Abul-Soud et al., 2015), vitamin C, and TSS in fruits, but decreased fruit acidity and firmness compared to compost tea (El-Sayed et al., 2016 b; Abul-Soud et al., 2015).

The present study was undertaken to determine effects of rooftop farming techniques, nutrient sources and cultivar on yield and quality of lettuce.

\section{MATERIALS AND METHODS}

This experiment was conducted on the rooftop of the Vegetable Crops building, Faculty of Agriculture, Cairo University, Giza, Egypt, during the winter seasons of 2016 and 2017.

\subsection{Experimental treatments}

The experiment included three factors (two hydroponic systems, two nutrient solutions and two head lettuce cultivars). The experiment was arranged in a completely randomized design with 3 replicates. Each experimental plot contained 20 plants.

\subsection{Materials}

\subsubsection{Hydroponic systems}

The two hydroponic systems used in the present study were deep flow technique and box system. 


\subsubsection{Deep Flow Technique (DFT) (Modified NFT System)}

Deep flow system was modified from the nutrient film technique system (NFT) by Rodríguez-Delfín et al. (2001). This system uses 4 inches diameter PVC pipes for culture, water and drainage channels, in which recirculation of the nutrient solution is twice a day, for $15 \mathrm{~min}$, and regulated by a pump located in a tank. The PVC pipes were fixed on an A-shaped metal frame ( $0.9 \mathrm{~m}$ width and $1.3 \mathrm{~m}$ height). The metal frame included 3 levels of PVC pipes on 2 sides with around $1 \%$ slope ensuring water flow back to a 501 tank in which the pump was positioned. Holes were made every $25 \mathrm{~cm}$ to put perforated black plastic bags, which were filled with a medium consisting of peat moss and vermiculite $(1: 1 \mathrm{v}: \mathrm{v})$. The system was supplied with $16 \mathrm{~mm}$ plastic hose, attached to a water submerged pump from 1 side and the other side was attached to the higher side of the PVC pipe. The plastic hose was used to supply plants with nutrient solution which was pumped out from the tank to each plant to distribute the solution from the higher to the lower side of the PVC pipe, returning the nutrient solution to the nutrient tank.

\subsubsection{Box System}

The box system consisted of a cultivation table, where plants were grown in a wooden box filled with a medium. The size of the box was 2 $\mathrm{m}$ length, $1 \mathrm{~m}$ width and $20 \mathrm{~cm}$ side's height. Boxes were elevated by 4 supports, to allow air circulation under the medium and to prevent excessive heat exchange from the medium to avoid root overheating and poor oxygenation of the water. The 2 back supports were $0.95 \mathrm{~cm}$; the 2 front supports were $90 \mathrm{~cm}$ in height allowing the excess nutrient solution to flow to a 501 tank placed below to be recycled. The internal part of the container was sealed with a black polyethylene waterproof sheet. The wooden box was filled with a medium consisting of peat moss and vermiculite $(1: 1 \mathrm{v}: \mathrm{v})$ up to a $10 \mathrm{~cm}$ height. The box was supplied with a closedcycle system consisting of irrigation (fertigation) and drainage systems. The irrigation system consisted of a water submerged pump connected to a timer that provided nutrient solution to plants through a delivery system composed by 3 lines of $16 \mathrm{~mm}$ plastic hose (black poly pipe); the first was the main line transporting nutrient solution from the tank to the horizontal sub-main line, located at the front side of the wooden box. The sub-main line transported nutrient solution from the main line to 4 distribution lines. Each distribution line was $2 \mathrm{~m}$ in length and each line had drippers of $4 \mathrm{l} \cdot \mathrm{hr}^{-1}$ capacity, fixed at $25 \mathrm{~cm}$ distances along the irrigation hoses.

The drainage system brought excess water (or nutrient solution) back to the main reservoir, placed under the cultivation box to be re-used. The drainage system consisted of 1 inch hole located in the bottom of the lower (front) side of the box, which was closed with a rubber gasket and a locknut, and connected with a rubber drain leading to the nutrient reservoir.

\subsubsection{Nutrient solutions}

Two nutrient solutions, viz., animal composttea and chemical nutrient solution of Modified Cooper (El-Behairy, 1994) as a control were used. The chemical nutrient solution was obtained from the Central Laboratory for Agricultural Climate, Agriculture Research Center, Cairo, Egypt. The compost tea was prepared by immersing 11 perforated bag containing animal compost in a 301 brewer tank. Air was supplied to the bottom of the brewer tank for aerobic process by an electric fish air pump; aeration for 7 days. The additives were 1 $\mathrm{kg}$ of molasses, $10 \mathrm{~g}$ baking yeast and humic (1 $\left.\mathrm{ml} \cdot \mathrm{l}^{-1}\right)$. The solution was used for a week, after that a new compost tea was prepared. Chemical composition of the compost tea and the chemical nutrient solution are presented in Table (1).

Table (1): The concentrations of different nutrient solutions (ppm).

\begin{tabular}{|l|c|c|}
\hline Elements & $\begin{array}{c}\text { Animal compost } \\
\text { extract }\end{array}$ & $\begin{array}{c}\text { Mineral nutrition } \\
\text { (Modified Cooper) }\end{array}$ \\
\hline $\mathbf{N}$ & 159 & 200 \\
\hline $\mathbf{P}$ & 17 & 60 \\
\hline $\mathbf{K}$ & 94 & 300 \\
\hline $\mathbf{C a}$ & 73 & 170 \\
\hline $\mathbf{M g}$ & 30 & 50 \\
\hline $\mathbf{F e}$ & 7.5 & 12 \\
\hline $\mathbf{M n}$ & 0.8 & 2 \\
\hline $\mathbf{C u}$ & 0.1 & 0.1 \\
\hline $\mathbf{Z n}$ & 0.1 & 0.1 \\
\hline $\mathbf{B}$ & 0.4 & 0.3 \\
\hline $\mathbf{M o}$ & & 0.2 \\
\hline $\mathbf{E c}$ & 1.5 & 1.5 \\
\hline $\mathbf{p H}$ & 7.5 & 7.2 \\
\hline
\end{tabular}

\subsubsection{Cultivars}

The third factor under the investigation was two head lettuce cultivars, namely, 'Big Bell' (Bakker Brother, Holland) and 'Chianti' (Syngenta, Chile).

\subsection{Cultivation and fertigation}

The seedlings (20 day-old) of the crisp head 
lettuce were transplanted directly into the box and PVC pipes on the $2^{\text {nd }}$ and the $4^{\text {th }}$ October 2016 and 2017, respectively. The density of transplants was 16 plant $\mathrm{m}^{-2}$ in the box system (the space between rows in the box system was $20 \mathrm{~cm}$, while the space between plants was 25 $\mathrm{cm}$ ) and 4 plants per $1 \mathrm{~m}$ length in DFT, i.e., the space between the plants inside the PVC pipe was $25 \mathrm{~cm}$. So, each plot contained 16 plants. All lettuce plants in both systems were fertigated twice a day, each for $15 \mathrm{~min}$. The EC level of all nutrient solutions was adjusted at $1.5 \mathrm{~mm} \cdot \mathrm{hos}^{-1}$.

\subsection{Data Recorded}

2.4.1.Growth characters and yield: At harvest (70 days after transplanting), all plants (16 per plot) in each pipe in the DFT and box systems were weighed to determine yield per plot. Thereafter, a random sample of 5 plants was taken from each replicate (15 plants from each treatment) to measure plant fresh weight, head fresh weight and head diameter.

2.4.2. Chemical analysis: The same samples were used to determine the following chemical analysis:

2.4.2.1. Chlorophyll content: The mean of 3 readings of the third wrapper leaf from 3 plants per plot was measured using a Minolta SPAD502 meter (Spectrum Technologies Inc., Plainfield, IL.);

2.4.2.2. Total soluble solids: The percents of total soluble solids (TSS) were measured using Digital Refractometer SR-95(medline scientific, chalgrove, Oxon, UK.

2.4.2.3. Dry matter $(\%)$ and total sugars: to determine dry matter percent in the leaves, $100 \mathrm{~g}$ of leaves were oven dried at $70^{\circ} \mathrm{C}$ till a constant weight and then dry matter percentage calculated. The dried samples were fine ground, and total sugars were determined spectrophotometrically using $5 \%$ phenol/sulfuric acid reagent as described in A.O.A.C. (1990).

2.4.2.4. Nutrients and nitrate contents: The $N$, $\mathrm{P}, \mathrm{K}$ and nitrates concentrations were determined on a dry weight basis of wrapper leaves. The total nitrogen, phosphorus and potassium concentrations were determined by the Kjeldahl method, colorimetrically at $680 \mathrm{~nm}$ using a spectrophotometer (Hitachi, U-1000 Lab X service, Columbus, ohio, USA.) and Gallenkamp flame photometer A. Gallenkamp \& Co. Ltd., London, UK respectively, according to procedures described by Cottenie et al. (1982). Assessment of $\mathrm{NO}_{3}$ in lettuce heads was determined with the Brucine method reported by Holty and Potworowski (1972).

\subsection{Statistical analyses}

Data of the two seasons were subjected to statistical analysis according to Gomez and Gomez (1984). Statistical analysis was performed by using GenStat Discovery Edition 3. The data were evaluated by analysis of variance and the means of values were compared by the Least Significant Difference test (LSD) (p $=0.05$ ).

\section{RESULTS}

\subsection{Plant growth characters and total yield}

The effects of the production systems, nutrient solutions, lettuce cultivars and their interactions on plant growth characters and yield are presented in Table (2). Plants produced in the box were significantly heavier and had greater head weight and diameter as well as higher yield than those produced in deep flow system. Using mineral nutrition resulted in significantly greater plant weight, head fresh weight, head diameter and yield than using organic nutrition. Average fresh weight of plant, head and total yield and head diameter were significantly greater in 'BigBell' as compared with 'Chianti'.

Concerning the effect of the different interactions on plant growth characters, mineral nutrition gave higher values of plant fresh weight, total yield per $\mathrm{m}^{2}$, head fresh weight and head diameter in each hydroponic system, and the highest values were recorded for lettuce plants grown in the box system and fertigated with mineral solution.

With regard to the interaction between the production system and cultivars, data presented in the same table indicated that 'Big Bell' had significantly higher values of plant fresh weight, head fresh weight, head diameter and total yield per $\mathrm{m}^{2}$ in both systems in both seasons. The highest values of these characters were noticed with 'Big Bell' grown in the box system.

Regarding the interaction between nutrient solution and cultivars, when lettuce plants received organic nutrition, 'Big Bell' showed significantly higher values of plant fresh weight and total yield per $\mathrm{m}^{2}$ (in the second season) as well as head fresh weight, head diameter (in both seasons), as compared with 'Chianti'. All vegetative growth characters and yield were also greater in 'Big Bell' (in both seasons), when plants received mineral fertilizer.

The interaction among production system, nutrient solution and lettuce cultivars was significant (Table 3). In this respect 'Big Bell' cultivar, grown in the box system and 
Table (2): Effects of hydroponic systems, nutrient solutions, cultivars and their second order interactions on plant weight, head weight, head diameter and the total yield of lettuce.

\begin{tabular}{|c|c|c|c|c|c|c|c|c|c|c|}
\hline \multirow[t]{2}{*}{$\begin{array}{l}\text { Hydroponic } \\
\text { systems }\end{array}$} & \multirow[t]{2}{*}{$\begin{array}{l}\text { Nutrient } \\
\text { solutions }\end{array}$} & \multirow[t]{2}{*}{ Cultivars } & \multicolumn{2}{|c|}{ Plant weight (g) } & \multicolumn{2}{|c|}{ Head weight (g) } & \multicolumn{2}{|c|}{$\begin{array}{l}\text { Head diameter } \\
\quad(\mathrm{cm})\end{array}$} & \multicolumn{2}{|c|}{ Yield $\left(\mathrm{kg} / \mathrm{m}^{2}\right)$} \\
\hline & & & 2016 & 2017 & 2016 & 2017 & 2016 & 2017 & 2016 & 2017 \\
\hline Deep Flow & & & 323.88 & 425.43 & 265.70 & 316.58 & 5.85 & 6.15 & 5.31 & 6.58 \\
\hline Box & & & 444.53 & 486.68 & 360.60 & 348.33 & 6.98 & 6.88 & 7.13 & 7.60 \\
\hline \multirow[t]{7}{*}{ LSD at 0.5} & & & 52.82 & 58.18 & 37.76 & 27.0 & 0.92 & 0.54 & 0.86 & 0.90 \\
\hline & Mineral & & 487.75 & 518.68 & 403.70 & 378.33 & 7.21 & 6.93 & 7.96 & 8.10 \\
\hline & Organic & & 280.65 & 393.43 & 222.60 & 286.58 & 5.61 & 5.85 & 4.74 & 6.08 \\
\hline & LSD at 0.5 & & 16.8 & 58.18 & 37.76 & 27.0 & 0.92 & 0.54 & 0.86 & 0.90 \\
\hline & & Chianti & 329.78 & 387.60 & 266.13 & 270.43 & 5.75 & 5.81 & 5.36 & 6.12 \\
\hline & & Big-Bell & 438.63 & 524.50 & 360.18 & 394.48 & 7.08 & 6.98 & 7.33 & 8.06 \\
\hline & & LSD at 0.5 & 52.8 & 58.18 & 37.76 & 27.0 & 0.92 & 0.54 & 0.86 & 0.90 \\
\hline \multirow{4}{*}{ Deep Flow } & \multicolumn{10}{|c|}{ Interaction between Hydroponic systems and Nutrient solutions } \\
\hline & Mineral & & 425.20 & 479.15 & 350.80 & 369.45 & 6.55 & 6.54 & 6.97 & 7.56 \\
\hline & Organic & & 222.55 & 371.70 & 180.60 & 263.70 & 5.15 & 5.77 & 3.65 & 5.61 \\
\hline & Mineral & & 550.30 & 558.20 & 456.60 & 387.20 & 7.88 & 7.33 & 8.95 & 8.65 \\
\hline Box & Organic & & 338.75 & 415.15 & 264.60 & 309.45 & 6.08 & 6.44 & 5.32 & 6.55 \\
\hline \multicolumn{2}{|l|}{ LSD at 0.5} & & 74.7 & 82.28 & 53.4 & 56.47 & 1.30 & 0.80 & 1.22 & 1.30 \\
\hline \multicolumn{11}{|c|}{ Interaction between Hydroponic systems and Cultivars } \\
\hline \multirow[t]{2}{*}{ Deep Flow } & & Chianti & 280.30 & 354.50 & 228.20 & 259.65 & 5.62 & 5.53 & 4.64 & 5.60 \\
\hline & & Big-Bell & 367.45 & 496.35 & 303.20 & 373.50 & 6.07 & 6.77 & 5.98 & 7.57 \\
\hline \multirow[t]{2}{*}{ Box } & & Chianti & 379.25 & 420.70 & 304.05 & 281.20 & 5.88 & 6.09 & 6.09 & 6.64 \\
\hline & & Big-Bell & 509.80 & 552.65 & 417.15 & 415.45 & 8.08 & 7.68 & 8.18 & 8.56 \\
\hline \multicolumn{2}{|l|}{ LSD at 0.5} & & 74.7 & 82.28 & 53.4 & 56.47 & 1.30 & 0.80 & 1.22 & 1.30 \\
\hline \multicolumn{11}{|c|}{ Interaction between Nutrient solutions and Cultivars } \\
\hline & \multirow[t]{2}{*}{ Mineral } & Chianti & 412.30 & 448.95 & 338.90 & 305.50 & 6.45 & 6.24 & 6.67 & 7.04 \\
\hline & & Big-Bell & 563.20 & 588.40 & 468.50 & 451.15 & 7.98 & 7.63 & 9.24 & 9.17 \\
\hline & \multirow[t]{2}{*}{ Organic } & Chianti & 247.25 & 326.25 & 193.35 & 235.35 & 5.05 & 5.38 & 4.06 & 5.20 \\
\hline & & Big-Bell & 314.05 & 460.60 & 251.85 & 337.80 & 6.18 & 6.83 & 4.92 & 6.96 \\
\hline \multicolumn{2}{|l|}{ LSD at 0.5} & & 74.7 & 82.28 & 53.4 & 56.47 & 1.30 & 0.80 & 1.22 & 1.30 \\
\hline
\end{tabular}


Table (3): Effects of the interaction among hydroponic systems, nutrient solutions and cultivars on plant weight head weight, head diameter and the total yield of lettuce .

\begin{tabular}{|c|c|c|c|c|c|c|c|c|c|c|}
\hline \multirow[t]{2}{*}{$\begin{array}{l}\text { Hydroponic } \\
\text { systems }\end{array}$} & \multirow{2}{*}{$\begin{array}{l}\text { Nutrient } \\
\text { solutions }\end{array}$} & \multirow{2}{*}{ Cultivars } & \multicolumn{2}{|c|}{$\begin{array}{c}\text { Plant } \\
\text { weight }(g)\end{array}$} & \multicolumn{2}{|c|}{$\begin{array}{l}\text { Head weight } \\
\text { (g) }\end{array}$} & \multicolumn{2}{|c|}{$\begin{array}{l}\text { Head diameter } \\
\text { (cm) }\end{array}$} & \multicolumn{2}{|c|}{ Yield $\left(\mathrm{kg} / \mathrm{m}^{2}\right)$} \\
\hline & & & 2016 & 2017 & 2016 & 2017 & 2016 & 2017 & 2016 & 2017 \\
\hline \multirow[t]{4}{*}{ Deep Flow } & \multirow[t]{2}{*}{ Mineral } & Chianti & 365.0 & 410.1 & 296.2 & 308.4 & 6.47 & 6.05 & 5.970 & 6.666 \\
\hline & & Big-Bell & 485.4 & 548.2 & 405.4 & 430.5 & 6.62 & 7.02 & 7.960 & 8.448 \\
\hline & \multirow[t]{2}{*}{ Organic } & Chianti & 195.6 & 298.9 & 160.2 & 210.9 & 4.77 & 5.01 & 3.308 & 4.530 \\
\hline & & Big-Bell & 249.5 & 444.5 & 201.0 & 316.5 & 5.52 & 6.52 & 4.000 & 6.695 \\
\hline \multirow[t]{4}{*}{ Box } & \multirow[t]{2}{*}{ Mineral } & Chianti & 459.6 & 487.8 & 381.6 & 302.6 & 6.43 & 6.42 & 7.374 & 7.405 \\
\hline & & Big-Bell & 641 & 628.6 & 531.6 & 471.8 & 9.33 & 8.23 & 10.518 & 9.888 \\
\hline & \multirow[t]{2}{*}{ Organic } & Chianti & 298.9 & 353.6 & 226.5 & 259.8 & 5.32 & 5.75 & 4.802 & 5.865 \\
\hline & & Big-Bell & 378.6 & 476.7 & 302.7 & 359.1 & 6.83 & 7.13 & 5.84 & 7.225 \\
\hline \multicolumn{3}{|c|}{ LSD at 0.5} & 105.6 & 116.4 & 75.52 & 94.0 & 1.84 & 1.28 & 1.727 & 1.892 \\
\hline
\end{tabular}

received mineral nutrition exhibited the highest values of plant fresh weight, head fresh weigh, total yield per $\mathrm{m}^{2}$ and head diameter, while 'Chianti' showed the lowest values of all these characters when plants were grown in deep flow system and fertigated with organic nutrition.

\subsection{Chlorophyll content}

As shown in Table (4), Spad reading of chlorophyll was significantly higher in plants grown in box system than that recorded in the leaves of plants obtained from deep flow system. Also, plants fertigated with mineral solution showed higher Spad reading than those fertigated with organic solution. These results were true in both production systems and both cultivars. Finally, leaves of 'Big- Bell' markedly exhibited higher Spad readings than those of 'Chianti'. These results were also achieved in both systems of production.

The interaction among cultivars, production systems and nutrient solutions was significant. The highest Spad value was read in the leaves of 'Big Bell', produced in the box system and fertigated with mineral solution. Reversely, the lowest value of chlorophyll reading was detected in the leaves of 'Chianti', produced in the deep flow technique system and got organic solution as a fertilizer.

\subsection{Dry matter percentage}

The 'Big- Bell', the box system and the mineral solution had plants containing a higher dry matter percentage as compared with 'Chianti', deep flow technique system and organic solution, respectively (Table 4).
Regarding the different interactions, using mineral solution in fertigation of lettuce plants led to a significant increase in the dry matter percentage in the plants of both production systems in both cultivars. Also, 'Big Bell' plants contained significantly a higher percentage of dry matter in both production systems and whether these plants were fertigated with mineral or organic solution, as compared to the plants of 'Chianti' cultivar.

The interaction among cultivars, production systems and nutrient solutions revealed that the highest dry matter percentage was achieved in the plants of 'Big Bell', produced in the box system and fertigated with mineral solution. In contrast, the least dry matter percentage was found in the plants of 'Chianti', produced in the deep flow technique system and received organic solution as a fertilizer (Table 5).

\subsection{Leaves concentration of NPK}

Data presented in Table (6) revealed that the plants grown in the box system contained significantly higher concentration of $\mathrm{K}$ than those grown in deep flow technique system. On the other hand, there were no significant differences in the concentrations of $\mathrm{N}$ and $\mathrm{P}$ between the plants grown in the box and the deep flow system.

Mineral nutrition recorded significant increases in $\mathrm{P}$ and $\mathrm{K}$ concentrations in the plants got mineral nutrition as compared with those received organic nutrition. On the other hand, there were no significant differences in the concentration of $\mathrm{N}$ between plants received 
Table (4): Effect of hydroponic systems, nutrient solutions, cultivars and their second order interaction on dry matter contents and chlorophyll reading of lettuce leaves

\begin{tabular}{|c|c|c|c|c|c|c|}
\hline \multirow[t]{2}{*}{$\begin{array}{l}\text { Hydroponic } \\
\text { systems }\end{array}$} & \multirow[t]{2}{*}{ Nutrient solutions } & \multirow[t]{2}{*}{ Cultivars } & \multicolumn{2}{|c|}{ Dry matter $(\%)$} & \multicolumn{2}{|c|}{$\begin{array}{l}\text { Chlorophyll } \\
\text { (Spad) }\end{array}$} \\
\hline & & & 2016 & 2017 & 2016 & 2017 \\
\hline Deep Flow & & & 3.01 & 3.24 & 22.88 & 24.46 \\
\hline Box & & & 3.93 & 4.06 & 28.75 & 27.00 \\
\hline \multirow[t]{7}{*}{ LSD at 0.5} & & & 0.46 & 0.44 & 3.05 & 3.08 \\
\hline & Mineral & & 3.95 & 4.14 & 27.48 & 27.70 \\
\hline & Organic & & 2.99 & 3.17 & 25.17 & 24.56 \\
\hline & LSD at 0.5 & & 0.46 & 0.44 & 3.05 & 3.08 \\
\hline & & Chianti & 2.92 & 2.98 & 24.11 & 25.20 \\
\hline & & Big-Bell & 4.01 & 4.32 & 28.53 & 27.15 \\
\hline & & LSD at 0.5 & 0.46 & 0.44 & 3.05 & 3.08 \\
\hline \multicolumn{7}{|c|}{ Interaction between Hydroponic systems and Nutrient solutions } \\
\hline \multirow[t]{2}{*}{ Deep Flow } & Mineral & & 3.62 & 3.87 & 24.67 & 25.39 \\
\hline & Organic & & 2.40 & 2.61 & 23.10 & 23.52 \\
\hline \multirow[t]{2}{*}{ Box } & Mineral & & 4.28 & 4.40 & 30.28 & 30.19 \\
\hline & Organic & & 3.57 & 3.72 & 27.23 & 25.60 \\
\hline LSD at 0.5 & & & 0.65 & 0.62 & 4.31 & 4.35 \\
\hline \multicolumn{7}{|c|}{ Interaction between Hydroponic systems and Cultivars } \\
\hline \multirow[t]{2}{*}{ Deep Flow } & & Chianti & 2.63 & 2.63 & 21.99 & 23.07 \\
\hline & & Big-Bell & 3.39 & 3.85 & 25.78 & 25.85 \\
\hline \multirow[t]{2}{*}{ Box } & & Chianti & 3.22 & 3.33 & 26.23 & 27.33 \\
\hline & & Big-Bell & 4.63 & 4.80 & 31.28 & 28.46 \\
\hline LSD at 0.5 & & & 0.65 & 0.62 & 4.31 & 4.35 \\
\hline \multicolumn{7}{|c|}{ Interaction between Nutrient solutions and Cultivars } \\
\hline & \multirow[t]{2}{*}{ Mineral } & Chianti & 3.31 & 3.10 & 25.52 & 26.32 \\
\hline & & Big-Bell & 4.59 & 5.165 & 29.425 & 29.265 \\
\hline & \multirow{2}{*}{ Organic } & Chianti & 2.54 & 2.86 & 22.70 & 24.09 \\
\hline & & Big-Bell & 3.43 & 3.48 & 27.63 & 25.04 \\
\hline LSD at 0.5 & & & 0.65 & 0.62 & 4.31 & 4.35 \\
\hline
\end{tabular}

Table (5): Effects of the interaction among hydroponic systems, nutrient solutions and cultivars on dry matter contents and chlorophyll reading of lettuce leaves.

\begin{tabular}{|c|c|c|c|c|c|c|}
\hline Hydroponic systems & \multirow{2}{*}{ Nutrient solutions } & \multicolumn{2}{|c|}{ Dry matter (\%) } & \multicolumn{2}{c|}{ Chlorophyll (Spad) } \\
\cline { 3 - 7 } & & Cultivars & $\mathbf{2 0 1 6}$ & $\mathbf{2 0 1 7}$ & $\mathbf{2 0 1 6}$ & $\mathbf{2 0 1 7}$ \\
\hline \multirow{3}{*}{ Deep Flow } & \multirow{2}{*}{ Mineral } & Chianti & 2.88 & 2.75 & 22.00 & 23.9 \\
\cline { 3 - 7 } & & Big-Bell & 4.36 & 4.98 & 27.34 & 26.88 \\
\cline { 3 - 7 } & \multirow{2}{*}{ Organic } & Chianti & 2.38 & 2.51 & 21.97 & 22.24 \\
\cline { 3 - 7 } & & Big-Bell & 2.41 & 2.71 & 24.22 & 24.81 \\
\hline \multirow{2}{*}{ Box } & \multirow{2}{*}{ Mineral } & Chianti & 3.74 & 3.45 & 29.04 & 28.73 \\
\cline { 3 - 7 } & & Big-Bell & 4.82 & 5.35 & 31.51 & 31.65 \\
\hline \multirow{2}{*}{ Organic } & Chianti & 2.69 & 3.20 & 23.42 & 25.93 \\
\cline { 3 - 7 } & & Big-Bell & 4.44 & 4.24 & 31.04 & 25.27 \\
\hline & \multirow{2}{*}{ LSD at 0.5 } & & 0.92 & 0.87 & 6.10 & 6.15 \\
\hline
\end{tabular}


Table (6): Effects of hydroponic systems, nutrient solutions, cultivars and their second order interactions on $\mathbf{N}, \mathbf{P}$ and $\mathrm{K}$ concentrations of lettuce leaves

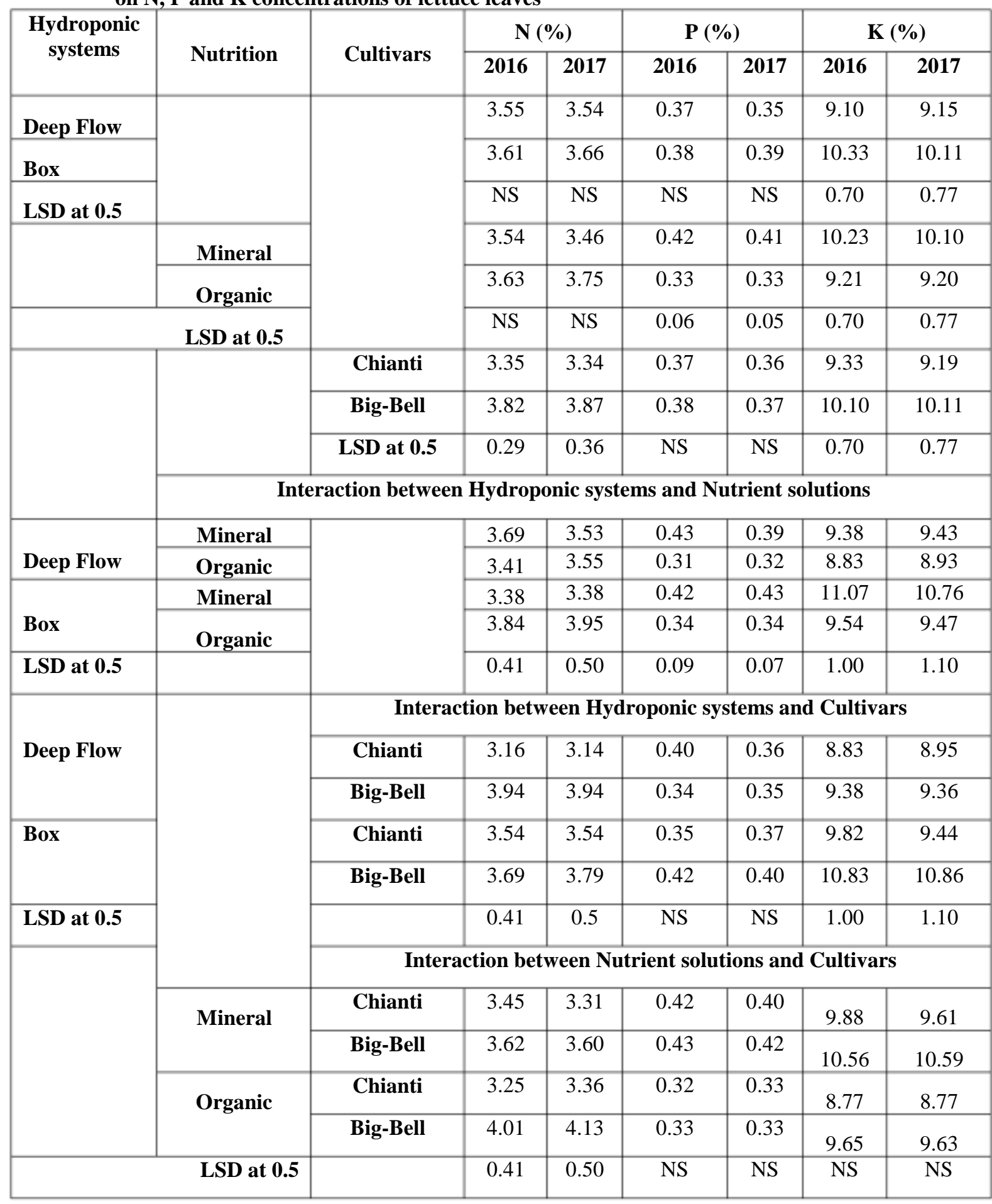

mineral nutrition and those received organic nutrition.

Nitrogen and potassium concentrations in the leaves of 'Big-Bell' were significantly higher than those recorded in the leaves of Chianti'. On the other hand, cultivars had no remarkable influence on $\mathrm{P}$ concentration.

The interaction between the production system and nutrient solution on the concentrations of $\mathrm{N}, \mathrm{P}$ and $\mathrm{K}$ in plants was significant. Under the conditions of growing in the deep flow system, there were no significant 
differences between mineral and organic nutrition in $\mathrm{N}$ and $\mathrm{K}$ concentrations, while $\mathrm{P}$ concentration in the plant received mineral nutrition was higher than those received organic nutrition in both seasons. Under the conditions of growing in the box system, $\mathrm{P}$ and $\mathrm{K}$ concentrations in the plants received mineral nutrition were higher than those received organic nutrition in the second season and in both seasons, respectively. In contrast, $\mathrm{N}$ concentration in the plant took significantly traverse trend in both seasons, where $\mathrm{N}$ leaves of 'Big Bell' grown in the box system and fertilized with organic and mineral nutrition, respectively, while the highest $\mathrm{K}$ concentration was recorded in in the leaves of 'Big Bell' grown in the box system and fertilized with mineral nutrition. On the contrary, the $\mathrm{L}$ east $\mathrm{N}$ and $\mathrm{K}$ concentrations were reported in the leaves of ' Chianti', grown in the deep flow technique system and received organic nutrition, while the lowest $\mathrm{P}$ concentration was found in the leaves of 'Big Bell' grown in the deep flow system and received organic nutrition (Table 7 ).

Table (7): Effects of the interaction among hydroponic systems, nutrient solutions and cultivars on $N, P$ and $K$ concentrations of lettuce leaves .

\begin{tabular}{|c|c|c|c|c|c|c|c|c|}
\hline \multirow{3}{*}{ Hydroponic systems } & \multirow{3}{*}{ Nutrient solutions } & \multirow{2}{*}{ Cultivars } & \multicolumn{2}{|c|}{$\mathbf{N}(\%)$} & \multicolumn{2}{|c|}{$\mathrm{P}(\%)$} & \multicolumn{2}{|c|}{$\mathbf{K}(\%)$} \\
\hline & & & 2016 & 2017 & 2016 & 2017 & 2016 & 2017 \\
\hline & & \multicolumn{7}{|c|}{ Interaction among System, Nutrition and Cultivars } \\
\hline \multirow[t]{4}{*}{ Deep Flow } & \multirow[t]{2}{*}{ Mineral } & Chianti & 3.38 & 3.38 & 0.45 & 0.38 & 018 & 027 \\
\hline & & Big-Bell & 3.99 & 3.79 & 0.40 & 0.39 & 9.57 & 9.49 \\
\hline & \multirow{2}{*}{ Organic } & Chianti & 2.94 & 3.00 & 0.35 & 0.33 & 8.48 & 8.63 \\
\hline & & Big-Bell & 3.89 & 4.10 & 0.27 & 0.30 & 9.18 & 9.22 \\
\hline \multirow[t]{4}{*}{ Box } & \multirow[t]{2}{*}{ Mineral } & Chianti & 3.52 & 3.35 & 0.40 & 0.41 & 10.58 & 9.96 \\
\hline & & Big-Bell & 3.25 & 3.42 & 0.45 & 0.45 & 11.55 & 11.69 \\
\hline & \multirow[t]{2}{*}{ Organic } & Chianti & 3.55 & 3.72 & 0.29 & 0.32 & 9.06 & 8.91 \\
\hline & & Big-Bell & 4.13 & 4.17 & 0.39 & 0.36 & 10.11 & 10.03 \\
\hline LSD at 0.5 & & & 0.58 & 0.71 & 0.12 & 0.10 & 1.41 & 1.55 \\
\hline
\end{tabular}

concentration in organic nutrition was higher than that determined in mineral nutrition.

The effect of the interaction between systems and cultivars on the concentrations of $\mathrm{N}$ and $\mathrm{K}$ was significant in some cases, while such effect on $\mathrm{P}$ concentration was not significant. Under the conditions of deep flow technique system, the 'Big Bell' plants had significantly higher $\mathrm{N}$ concentration than ' Chianti', while there were no significant differences in $\mathrm{K}$ concentration between the two cultivars. Under the conditions of growing in the box system, there were no significant differences between the two cultivars in $\mathrm{N}$ concentration, while $\mathrm{K}$ concentration in 'Big Bell' was significantly higher than in 'Chianti'.

The Interaction between nutrition and cultivars for $\mathrm{N}, \mathrm{P}$ and $\mathrm{K}$ concentrations was not significant, except in the case of 'Big Bell' plants, which had a higher $\mathrm{N}$ concentration than 'Chianti' receiving organic nutrition.

The interaction among the production system, nutrient solution and lettuce cultivars was significant. In this respect, the highest concentrations of $\mathrm{N}, \mathrm{P}$ and $\mathrm{K}$ were registered

\subsection{Leaf content of organic substances}

Data presented in Tables ( 8 and 9) revealed the influence of hydroponic systems, nutrient solutions, cultivars and their interactions on leaves content of organic substances, viz., nitrate, total sugars and total soluble solids (TSS) in lettuce leaves.

Plants produced in the box had significantly higher contents of nitrate (in the second season) and total sugars (in both seasons) in their leaves than those produced in the deep flow technique system. On the other hand, there were no significant differences between the two hydroponic systems in the percentage of TSS.

Using mineral nutrition resulted in significantly higher contents of nitrate and total sugars than using organic nutrition. On the other hand, there were no significant differences between the organic and the mineral nutrition in the percentage of TSS in the leaves.

Nitrate, total sugars and TSS\% in lettuce leaves of 'Big-Bell' were significantly higher than those detected in the leaves of 'Chianti'.

The effects of the different interactions on nitrate, total sugars and TSS in lettuce leaves 
Table (8): Effects of hydroponic systems, nutrient solutions, cultivars and their second order interactions on nitrate, total sugars and TSS of lettuce .

\begin{tabular}{|c|c|c|c|c|c|c|c|c|}
\hline \multirow{2}{*}{$\begin{array}{l}\text { Hydroponic } \\
\text { systems }\end{array}$} & \multirow{2}{*}{$\begin{array}{l}\text { Nutrient } \\
\text { solutions }\end{array}$} & \multirow[t]{2}{*}{ Cultivars } & \multicolumn{2}{|c|}{ Nitrate (ppm) } & \multicolumn{2}{|c|}{ Sugars (\%) } & \multicolumn{2}{|c|}{ TSS (\%) } \\
\hline & & & 2016 & 2017 & 2016 & 2017 & 2016 & 2017 \\
\hline Deep Flow & & & 577.7 & 585.2 & 102.32 & 103.45 & 3.06 & 2.82 \\
\hline Box & & & 624.0 & 666.0 & 117.32 & 117.65 & 3.23 & 3.28 \\
\hline \multirow{8}{*}{ LSD at 0.5} & & & 83.16 & 62.58 & 10.43 & 9.21 & NS & NS \\
\hline & Mineral & & 750.1 & 768.3 & 119.88 & 116.12 & 3.43 & 3.18 \\
\hline & Organic & & 451.6 & 483 & 100.33 & 104.99 & 2.86 & 2.93 \\
\hline & LSD at 0.5 & & 83.16 & 62.58 & 10.43 & 9.21 & NS & NS \\
\hline & & Chianti & 499.9 & 493.8 & 100.17 & 99.75 & 2.73 & 2.61 \\
\hline & & Big-Bell & 701.8 & 757.4 & 120.03 & 121.35 & 3.56 & 3.50 \\
\hline & & & 3.16 & 62.58 & 10.43 & 9.21 & 0.44 & 0.56 \\
\hline & & & \multicolumn{6}{|c|}{ Interaction between Hydroponic systems and Nutrient solutions } \\
\hline \multirow[b]{2}{*}{ Deep Flow } & Mineral & & 747 & 745.3 & 110.00 & 107.19 & 3.36 & 2.94 \\
\hline & Organic & & 408.5 & 425.2 & 94.70 & 99.72 & 2.75 & 2.69 \\
\hline \multirow[b]{2}{*}{ Box } & Mineral & & 753.3 & 791.3 & 129.75 & 125.05 & 3.50 & 3.42 \\
\hline & Organic & & 494.6 & 540.8 & 105.95 & 110.25 & 2.96 & 3.17 \\
\hline LSD at 0.5 & & & 117.6 & 88.5 & 14.75 & 13.03 & 0.62 & 0.79 \\
\hline \multirow{3}{*}{ Deep Flow } & & & \multicolumn{6}{|c|}{ Interaction between Hydroponic systems and Cultivars } \\
\hline & & Chianti & 495.2 & 458.5 & 93.35 & 92.45 & 2.59 & 2.35 \\
\hline & & Big-Bell & 660.3 & 711.9 & 111.35 & 114.45 & 3.53 & 3.27 \\
\hline \multirow[t]{2}{*}{ Box } & & Chianti & 504.6 & 529.1 & 107.00 & 107.05 & 2.88 & 2.87 \\
\hline & & Big-Bell & 743.3 & 802.9 & 128.70 & 128.25 & 3.58 & 3.73 \\
\hline \multirow[t]{6}{*}{ LSD at 0.5} & & & 117.6 & 88.5 & 14.75 & 13.03 & 0.62 & 0.79 \\
\hline & & & \multicolumn{6}{|c|}{ Interaction between Nutrient solutions and Cultivars } \\
\hline & Mineral & Chianti & 600.2 & 566.9 & 107.70 & 103.54 & 3.09 & 2.78 \\
\hline & & Big-Bell & 900.0 & 969.7 & 132.05 & 128.7 & 3.78 & 3.58 \\
\hline & Organic & Chianti & 399.6 & 420.7 & 92.65 & 95.97 & 2.38 & 2.44 \\
\hline & & Big-Bell & 503.5 & 545.2 & 108.00 & 114.00 & 3.33 & 3.42 \\
\hline & & LSD at 0.5 & 117.6 & 88.5 & 14.75 & 13.03 & 0.62 & 0.79 \\
\hline
\end{tabular}

Table (9): Effects of the interaction among hydroponic systems, nutrient solutions and cultivars on nitrate, sugars and TSS of lettuce.

\begin{tabular}{|c|c|c|c|c|c|c|c|c|}
\hline \multirow[t]{2}{*}{ System } & \multirow{2}{*}{ Nutrition } & \multirow{2}{*}{ Cultivars } & \multicolumn{2}{|c|}{ Nitrate (ppm) } & \multicolumn{2}{|c|}{ Sugars (\%) } & \multicolumn{2}{|c|}{ TSS (\%) } \\
\hline & & & 2016 & 2017 & 2016 & 2017 & 2016 & 2017 \\
\hline \multirow[t]{4}{*}{ Deep Flow } & \multirow[t]{2}{*}{ Mineral } & Chianti & 556.9 & 510.2 & 104.6 & 99.57 & 3.00 & 2.50 \\
\hline & & Big-Bell & 937.0 & 980.4 & 115.4 & 114.8 & 3.72 & 3.37 \\
\hline & \multirow[t]{2}{*}{ Organic } & Chianti & 433.5 & 406.8 & 82.09 & 85.33 & 2.17 & 2.20 \\
\hline & & Big-Bell & 383.5 & 443.5 & 107.3 & 114.1 & 3.33 & 3.17 \\
\hline \multirow[t]{4}{*}{ Box } & \multirow[t]{2}{*}{ Mineral } & Chianti & 643.6 & 623.6 & 110.8 & 107.5 & 3.17 & 3.06 \\
\hline & & Big-Bell & 863.0 & 959.0 & 148.7 & 142.6 & 3.83 & 3.78 \\
\hline & \multirow[t]{2}{*}{ Organic } & Chianti & 365.7 & 434.6 & 103.2 & 106.6 & 2.58 & 2.67 \\
\hline & & Big-Bell & 623.6 & 646.9 & 108.7 & 113.9 & 3.33 & 3.67 \\
\hline LSD at 0.5 & & & 166.3 & 125.2 & 20.87 & 18.43 & 0.88 & 1.12 \\
\hline
\end{tabular}


were significant.Concerning the effect of interaction between production systems and nutrient solutions, as compared with mineral nutrition using organic nutrition resulted in significantly lower content of nitrate and total sugars in both hydroponic systems. Meanwhile, this interaction did not show significant effect on the TSS \% in the leaves.

In respect to the interaction between production system and cultivars, the data presented in the same table indicated that 'Big Bell' had significantly higher content of nitrate, total sugars and TSS\% than 'Chianti' in both hydroponic systems.

Regarding the interaction between nutrient solutions and cultivars, 'Big Bell' had significantly higher content of TSS and total sugars than Chianti cultivar in both nutrient solutions. 'Big Bell' had generally higher nitrate than 'Chianti' in both nutrient solutions in the second season and in mineral solution in the first season.

The interaction among the production system, nutrient solution and lettuce cultivars was significant. In this respect, 'Chianti' received organic nutrition and grown in the box system in the first season and too deep flow system in the second season, had the lowest content of nitrite. In contrast, the highest nitrate content was recorded in both seasons in 'Big Bell' grown in deep flow and fertilized with mineral nutrition. The highest content of total sugars and TSS was observed in 'Big Bell' produced in the box system and received mineral nutrition.

\section{DISCUSSION}

The present study aimed to study the effects of two production systems (deep flow technique and box systems) and two nutrient solutions (mineral and organic solutions) on plant growth and quality of two cultivars of crisp head lettuce, namely 'Chianti' and 'Big Bell'. The characters under investigations were plant growth characters (plant height, head diameter, head fresh weight, and the head dry weight), total yield, Chlorophyll content, dry matter percentage in leaves, percentage of TSS \%, total sugars, nutrients (N, P and $\mathrm{K}$ ) and nitrate concentrations in the leaves. It was clear that all studied characters were generally higher by using the box system, mineral solution as a fertilizer and 'Big Bell', as compared with the deep flow technique system, organic solution as a fertilizer and Chianti, respectively. The differences were significant for all characters, except for TSS\% between the two growing systems and the two nutrient solutions.

Concerning the production system, the increase in all characters due to using the box system may be attributed to the wider space for root development available in the box system. This system has been successfully used in a wide range of climates and proved to be more suitable for medium-bigger sized vegetables such as tomato, pepper, cucumber, eggplant and chili pepper, which need more space for root development. Indeed it is also good for carrots or leafy vegetables (lettuce, spinach, etc.) (Rodríguez-Delfín et al., 2001). On the other hand, the deep flow technique system was modified from NFT system. The original design was modified by the Centro de Investigación de Hidroponía y NutriciónMineral (CIHNM) of the Universidad Nacional Agraria La Molina (UNALM) in Lima, Perù, to make feasible the production of different vegetables and to adapt the technique to the nature of Latin American countries (Rodríguez-Delfín et al., 2001). A modified NFT system was successfully adopted in rooftop soilless gardens in Bologna (Italy) and Lima (Peru). The advantage of this system was that about $25 \mathrm{~mm}$ of nutrient solution are maintained in the culture channels, while the pump is off, enough level so that the roots are in permanent contact with the nutrient solution. The disadvantage of this system, as was observed in the present work, was the limited root growth, due to growing lettuce plants in small bags. The large size roots of plants grown in the box system may be contributed in more uptakes of the mineral elements, especially NPK.

Concerning nutrient solutions, using mineral nutrition resulted in significantly greater plant fresh weight, head fresh weight and head diameter as well as higher total yield than using organic nutrition. These results may be due to the existence of high concentrations of macro elements in mineral solution as compared to those found in the organic one. The concentrations of $\mathrm{N}, \mathrm{P}, \mathrm{K}, \mathrm{Ca}$ and $\mathrm{Mg}$ in the in mineral solution were $200,60,300,170$ and 50 ppm, while they were in the organic solution 159, 17, 94, 73 and $30 \mathrm{ppm}$, respectively (Table $1)$.

The superiority of 'Big Bell' in all the studied characters as compared with 'Chianti' may be attributed to the genetic variations between the cultivars. Several researchers came to such results. Madzivhandila (2005) evaluated the 
performance of fifteen crisp head lettuce cultivars, and revealed that among the cultivars tested, the best yielding cultivars were Dual Purpose (46.8 t $\left.\bullet \mathrm{ha}^{-1}\right)$, namely 'Great Lakes' (45.8 t•ha ${ }^{-1}$ ), Mohawk (44.3 t•ha $\left.{ }^{-1}\right)$ and 'Victory' (43.9 $\left.\mathrm{t} \bullet \mathrm{ha}^{-1}\right)$. Shahien et al. (2014), also found that lettuce cv. 'Dark Green' significantly exceeded 'Big-Bell' in all vegetative and nutritive quality characters and nitrate content. Maboko et al. (2015) evaluated 9 lettuce cultivars during winter season in South Africa and showed that head mass, height, diameter, uniformity, compactness, tip burn, disease tolerance and internal quality were significantly affected by cultivar choice. Inter and intra-specific diversity for uptake, translocation, distribution, and use of nutrients have been recognized for many years and numerous reviews have been reported by Bouain et al. (2014) and Holmes (2017). He et al. (2016) recorded positive correlations between shoot weight and root weight in lettuce cultivars. It was also reported that the content of nitrate in lettuce is limited by a head size (DevienneBarret et al., 2000) and nitrate content in soil (Liu et al., 2014).

Generally, the increase in NPK concentrations, due to the increase of root size, as was achieved by planting in the box system, or using a cultivar having big root system, or due to using high concentrations of NPK in nutrient solution, as in using mineral solution, may have contributed to increasing all vegetative growth characters, chlorophyll content, dry matter percentage TSS\% and total sugars in lettuce plants in the current investigation. Tittonell et al. (2003) reported that lettuce fresh weight increased when $\mathrm{N}$ rate was increased. Nitrogen is necessary for plant cell division. So, it is vital for plant growth (Shukla et al., 2014).

It is clear in the present study that leaf content of chlorophyll, dry matter, TSS and total sugars were higher in the plants fertigated with mineral solution as compared to those obtained organic solution as a fertilizer. Also, these results may be attributed to the high concentrations of $\mathrm{N}, \mathrm{P}$ and $\mathrm{K}$ in the mineral solution as compared to the organic one. It is well known that nitrogen is an essential constituent of chlorophyll (Shukla et al., 2014). Therefore, higher chlorophyll content was recorded at the high rate of nitrogen fertilization (Politycka and Golcz, 2004; Mahlangu et al., 2016).

It was reported that because nitrogen plays a critical role in the synthesis of amino acids, chlorophyll formation, leaf photosynthesis, it consequently led to an increase in plant growth, and yield of lettuce (Sukor, 2013). The high rate of nitrogen results in a high rate of photosynthesis, which may lead to enhancement in the net photosynthetic rate. The net photosynthetic rate leads to increases in total soluble sugars (TSS), which contribute to the synthesis and accumulation of dry matter $(\mathrm{Xu} e t$ al., 2016, Mahlangu et al., 2016). It was revealed that the increments in leaf dry weight may be attributed to nitrogen concentration and its effect on the rate of photosynthesis (Ekwe, 2015). Moreover, it was reported that the high contents of chlorophyll and total nitrogen in the leaves are associated with maximum lettuce yield (Mahlangu et al., 2016)

Concerning nitrate content, the low nitrate content in vegetables is very important for human health, due to its transformation to nitrites. Nitrate interacts with hemoglobin and affect transportation of blood oxygen (Santamaria, 2006). The present results clearly indicated that there was a significant difference in nitrate concentration, where it was higher in plants of 'Big Bell' and under the conditions of production in the box system and fertilization with mineral solution as compared with the plants of 'Chianti' produced in the deep flow system and fertigated with organic nutrition. In this regard, Frezza et al. (2005) indicated that nitrate content was significantly affected by the production system, where it was significantly higher when lettuce was produced in the soil as compared to producing in the flow system. Shahien et al. (2014) recorded a positive relationship between $\mathrm{K}$ concentration and nitrate accumulation. It was found in the present results also that plants with high $\mathrm{K}$ content has high nitrate concentration. In contrast, NurzyńskaWierdak (2009) reported that as the potassium doses increased the concentrations of $\mathrm{N}_{-} \mathrm{NO}_{3}$ decreased (but in the case of $\mathrm{KCl}$ as potassium source and not with $\mathrm{K}_{2} \mathrm{SO}_{4}$ ). The increase in the nitrogen fertilization rate for obtaining a higher yield, as in the case of using mineral nutrition, leads to excessive nitrate accumulation, particularly in leaf vegetables (Liu et al., 2014). Uwah et al. (2009) also reported that the content of nitrate in lettuce is depended on the nitrate concentration in the soil, and in the current investigation nitrate concentration in lettuce leaves were high in plants fertigated with mineral nutrition and had a high concentration of nitrogen. Shahien et al. (2014) found that 
substitution of mineral NPK in lettuce fertilization with organic fertilizers led to a significant decrease in the concentration of nitrate in lettuce leaves, and nitrate content of the 'Big-Bell' was significantly higher than the 'Dark Green'.

The interactions among production system, nutrient solution and lettuce cultivars indicated that the highest total yield per $\mathrm{m}^{2}$ (10.518 and $9.888 \mathrm{~kg} / \mathrm{m}^{2}$; i.e. 42.072 and 39.552 ton/fed., in the first and second seasons, respectively) was achieved by producing 'Big Bell' in the box system and fertigation with mineral nutrition. These results were attributed to growing a pronounced lettuce cultivar and ensure good growth conditions, i.e, good medium and ideal fertigation system. Shahien et al. (2014) obtained 30.67 and 32.53 ton/fed. using this cultivar and mineral NPK fertilizers under field conditions. However, the presence of high nitrate concentration in the lettuce plants under these conditions may lead the consumers to reject these plants, and prefer consuming 'Chianti' produced in the deep flow technique system under the conditions of organic fertigation. This treatment can be recommended from the present work for three reasons, firstly, because this treatment showed the least nitrate concentration in the leaves; secondly although this treatment produced the least yield per $\mathrm{m}^{2}$, however, the yield was relatively good (3.919 $\mathrm{kg} / \mathrm{m}^{2}$ (about 15.676 ton/fed) as an average of the two seasons) as compared to production under field conditions. These results may have been obtained due to planting lettuce plants at a high density under hydroponic conditions (64000/fed), while the plant density is about $40000 \mathrm{plant} / \mathrm{fed}$. The last reason for choosing this treatment is consuming a lower amount of water, consequently lower amount of nutrition solution, as compared to using box system and this will save water and reduce production cost.

\section{REFERENCES}

A.O.A.C. methods (1990). Association of official analytical chemists $15^{\text {th }}$ Ed. Washington, D.C,USA.

Abul-Soud M. A. (2015). Achieve food security of leafy vegetables in urban (how to create resilience cities?). Global J. Adv. Res., 2 (11):1695-1713.

Abul-Soud M.A., Emam M.S.A. and Abd ElRahman N.G. (2015). The potential use of vermicompost in soilless culture for producing strawberry. Int'l. J. Pl. \& Soil Sci., 8 (5): 1-15.

Bañez B.P. and Manipon F.R. (2000). Crop production under greenhouse and soil-less media culture (Los Baños conditions). Workshop of the Packaging of Hydroponics R\&D Program for High Value Crop Production in the Philippines. PCARRD, Los Baños, Laguna, Philippines.

Bouain N., Kisko M., Rouached A., Dauzat M., Lacombe B., Belgaroui N., Ghnaya T., Davidian J., Berthomieu P., Abdelly C. and Rouached H. (2014). Phosphate/zinc interaction analysis in two lettuce varieties reveals contrasting effects on biomass, photosynthesis, and dynamics of pi transport.BioMed Res. Int'l. 2014, 9 pp. avialabe at: http://dx.doi.org/10.1155/2014/548254

Carandang J.S., Busayong E.A., Punzalan E.C., Taylor R.W., Carandang J.L., Janairo J.I. and Co F.F. (2016). Comparative analysis on lettuce quality produced from urban agriculture and organic farming. Manila $\mathrm{J}$. Sci., 9: 136-147.

Cottenie A., Verloo M., Kiekens L., Velghe G. and Camerlynck R. (1982). Chemical Analysis of Plant and Soil. Laboratory of Analytical and Agrochemistry, State Univ. Ghent Belgium, pp 100-129.

Devienne-Barret F., Justes E., Machet J.M. and Mary B. (2000): Integrated control of nitrate uptake by crop growth rate and soil nitrate availability under field conditions. Ann. Bot., 86, 995-1005.

Eigenbrod C. and Gruda N. (2015). Urban vegetable for food security in cities. Agron. Sustain. Dev., 35 : 483-498.

Ekwe E. (2015). Effects of Nitrogen and Phosphorus on Photosynthesis and Growth of Silver Birch (Betula pendula Roth.) and Sunflower (Helianthus annuus L.). M.Sc. Thesis, Fac. Sci., Univ. Gothenburg.

El-Behairy U. A. (1994). The Effect of Levels of Phosphorus and Zinc in the Nutrient Solution on Macro and Micronutrients Uptake and Translocation in Cucumber (Cucumus sativus L.) Grown by Nutrient Film Technique. Ph.D Thesis, London University, London,UK. p.299.

El-Sayed S. F., Hassan H.A., Abul-Soud M. and Gad Doaa A. M. (2016a). Effect of substrate mixtures and nutrient solution sources on strawberry plants under closed hydroponic system. J. Product. \& Dev., 21(1): 97- 127. 
El-Sayed S. F., Hassan H.A., Abul-Soud M. and Gad Doaa A. M. (2016b). Effect of different substrates and nutrient solutions on vegetative growth, mineral content, production and fruit quality of strawberry. Zagazig J. Agric. Res., 43(6A): 1919- 1938.

El-Sayed Shereen S. F. (2017). Impact of integrated fertilization management on growth, productivity and quality of pea plants. Bull. Fac. Agric. Cairo Univ., 68:167182.

Foss J., Quesnel A., and Danielsson N. (2011). Sustainable rooftop agriculture. A strategic guide for city implementation. Blekinge Institute of Technology in Karlksrona, Sweden, 30 pp. Available at: bieb.ruaf.org/ruaf_bieb/upload/3694.pdf.

Frezza D., León A., Logegaray V., Chiesa A., Desimone M. and Diaz L. (2005). Soilless culture technology for high quality lettuce. Acta Hortic., 697:43-48.

Gawad I.O. (2014). The rise of rooftop gardens in informally developed areas in Egypt: exploring the abilities and boundaries. ARCHCAIRO 2014: $6^{\text {th }}$ International Conference of Responsive Urbanism in Informal Areas, 208-223. Available online at: https://pdflegend.com/.../the-rise-of-rooftopgardens-in-informally-developed-areas-in-e.

Germain A., Grégoire B., Hautecoeur I., Ayalon R. and Bergeron A. (2008). Guide to setting up your own edible rooftop garden. Published by Alternatives and the Rooftop Gardens Project, Montreal, QC, Canada, 80 pp. Accessed

at: http://archives.rooftopgardens.ca/files/how to EN FINAL lowres.pdf.

Gomez K. A. and Gomez A. A. (1984). Statistical Procedures for Agricultural Research $2^{\text {nd }}$ ed. John Willey and Sons (Pub). New york,USA.

Gupta G. and Mehta P. (2017). Roof top farming a solution to food security and climate change adaptation for cities. In: W. L. Filho (ed.), Climate Change Research at Universities. Springer International Publishing, Switzerland.

Hargreaves J.C., Adl M.S. and Warman P.R. (2009). Are compost teas an effective nutrient amendment in the cultivation of strawberries? Soil and plant tissue effects. J. Sci. Food Agric., 89: 390-397.

He J., Qin L. and Lee S.K. (2016). Root morphology, plant growth, nitrate accumulation and nitrogen metabolism of temperate lettuce grown in the tropics with elevated root-zone $\mathrm{CO}_{2}$ at different root-zone temperatures. Am. J. Plant Sci., 7:1821-1833.

Holmes S.C. (2017). Improving Lettuce Production in Deep Water Culture in the Southeastern United States. M.Sc. Thesis, Graduate Faculty, Auburn Univ. AL, USA.

Holty J.G. and Potworowski H.S. (1972). Brucine analysis for high nitrate concentrations. Environ. Sci. Tech., 6 (9):835-837.

Hosseny M. H. and Ahmed M.M.M (2009). Effect of nitrogen, organic and biofertilization on productivity of lettuce (cv. Romaine) in sandy soil under Assiut conditions. Assiut Univ. Bull. Environ. Res. 12(10: 79-93.

Ingham E.R. (2005). The Compost Tea Brewing Manual; Latest Methods and Research. $5^{\text {th }}$ edn. Soil Food Web Inc., Corvallis, OR.USA. 79 pp.

Kowalczyk K. (2016). Effect of different growing media in hydroponic culture on the yield and biological quality of lettuce (Lactuca sativa L. var. capitata) Acta Hortic., 1142: 105-110.

Lai W., Rekha P. D., Arun A. B. and Young C.C. (2008). Effect of mineral fertilizer, pig manure, and Azospirillum rugosum on growth and nutrient contents of Lactuca sativa L. Biol. Fertil. Soils ,45:155-164.

Lennard W.A. and Leonard B.V. (2006). A comparison of three different hydroponic sub-systems (gravel bed, floating and nutrient film technique) in an Aquaponic test system. Aquacult. Intl., 14:539-550.

Liu C., Sung Y., Chen B. and Lai H. (2014). Effects of nitrogen fertilizers on the growth and nitrate content of lettuce (Lactuca sativa L.). Int. J. Environ. Res. Public Health, 11: 4427-4440.

Madzivhandila L. L. R. (2005). Crisp head Lettuce (Lactuca sativa L.) Cultivar Evaluation and Response of Transplants to Nitrogen Nutrition. M.Sc Thesis, University Of Pretoria, South Africa, 52 pp.

Maboko M.M., Ncayiyana M. and Du Plooy C.P. (2015). Evaluation of butter head lettuce cultivars for winter production under a shade net structure. Acta Agric. Scand., Section B Soil \& Plant Sci., 65 (2): 177-181. (http://dx.doi.org/10.1080).

Mahlangu R.I.S., Maboko M.M., Sivakumar D., Soundy P. and Jifon J.. (2016). Lettuce (Lactuca sativa L.) growth, yield and quality 
response to nitrogen fertilization in a noncirculating hydroponic system. J. Plant Nut., 39(12):1766-1775.

Nurzyńska-Wierdak R. (2009). Growth and yield of garden rocket (Eruca sativa. Mill.) affected by nitrogen and potassium fertilization. Acta Sci. Pol., Hortorum Cultus (4): 23-33.

Politycka B. and Golcz A. (2004). Content of chloroplast pigments and anthocyanins in the leaves of Ocimum basilicum L. depending on nitrogen doses. Folia Hort. Ann., 16 (1): 2329.

Putra P.A. and Yuliando H. (2015). Soilless culture system to support water use efficiency and product quality: a Review. Agric. \& Agric. Sci. Procedia, 3: 283 - 288.

Reese N.M. (2014). An Assessment of the Potential for Urpan Rooftop Agriculture in West Oakland, California. M.Sc. Thesis, Univ. San Francisco,USA. 47 p.

Reis M., Coelho L., Beltrao J., Domingos I. and Moura M. (2013). Comparative response of lettuce (Lactuca sativa) to inorganic and organic compost fertilization. Recent Adv. En. Environ. Econom. Techn. Innova., 6168. www.wseas.us/e-library/conferences/ 2013/Paris/.../DECO-08.pdf.

Rodríguez-Delfín A., Chang $M$. and Hoyos M. (2001). Lettuce production in a Peruvian modified DFT system. Acta Hortic., 554:273278.

Roosta H. R. and Afsharipoor S. (2012). Effects of different cultivation media on vegetative growth, ecophysiolocal traits and nutrients concentration in strawberry under hydroponic and aquaponic cultivation systems. Adv. Environ. Biol., 6(2):543-555.

Sanders D. (2015). Lettuce Information Leaflet. Department of Horticultural Science, North Carolina State University. North Carolina, USA. http://content.ces.ncsu.edu lettuce.

Santamaria P. (2006). Nitrate in vegetables: toxicity, content, intake and $\mathrm{EC}$ regulation. J. Sci. Food Agric., 86:10-17.
Santos P.J.A. and Ocampo E.T.M. (2005). Snap hydroponics: development \& potential for urban vegetable production. Philippine J. Crop Sci., 30 (2): 3-11.

Sanyé-Mengual E., Orsini F., Oliver-Solà J, Rieradevall J., Montero J. I. and Gianquinto G. (2015). Techniques and crops for efficient rooftop gardens in Bologna, Italy. Agron. Sustain. Dev., 35:1477-1488

Shahein M.M, Afifi M.M. and Algharib A.M. (2014). Assessing the effect of humic substances extracted from compost and biogas manure on yield and quality of lettuce (Lactuca sativa L.). Amer.-Eurasian J. Agric. \& Environ. Sci., 14 (10): 996-1009.

Shukla R., Sharma Y. K. and Shukla A. K. (2014). Molecular mechanism of nutrient uptake in plants. Intl. J. Curr. Res. Ac. Rev., 2(12):142-154.

Sukor A. (2013). Effects of Cyanobacterial Fertilizers Compared to Commonly-Used Organic Fertilizers on Nitrogen Availability, Lettuce Growth, and Nitrogen Use Efficiency on Different Soil Textures. M.Sc. thesis, Colorado State Univ., Fort Collins, CO.,USA.

Tittonell P.A, de Grazia J. and Chiesa A. (2003). Nitrate and dry matter concentration in a leafy lettuce (Lactuca sativa L.) cultivar as affected by $\mathrm{N}$ fertilization and plant population. Agric. Tropic. Subtropic., 36: 8287.

Uwah E.I., Abah J., Ndahi N.P., and Ogugbuaja V.O. (2009). Concentration levels of nitrate and nitrite in soils and some leafy vegetables obtained in Maiduguri, Nigeria. J. App. Sci. Environ. Sanit., 4(3):233-244.

Welke S. (2005). The effect of compost extract on the yield of strawberries and the severity of Botrytis cinerea. J. Sustab. Agric., 25 (1): 57-68.

Xu H., Yan Lu Y. and Xie Z. (2016). Effects of silicon on maize photosynthesis and grain yield in black soils. Emirates J. Food Agric., 28(11):779-785. 


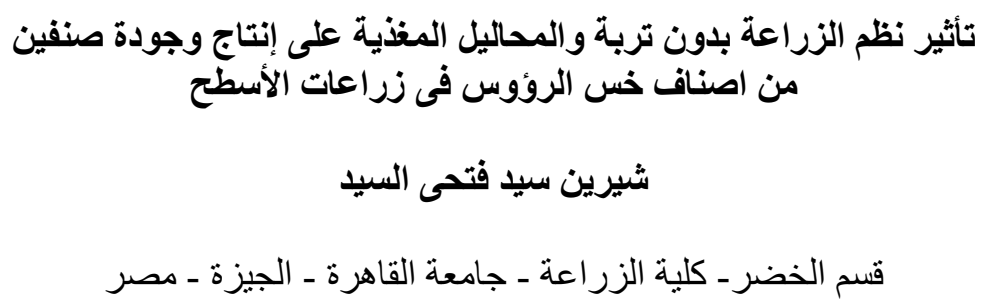

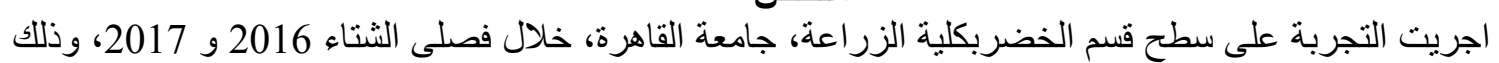

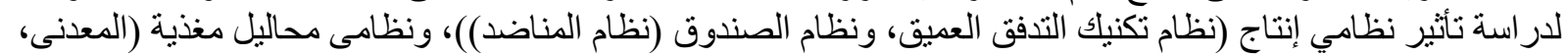

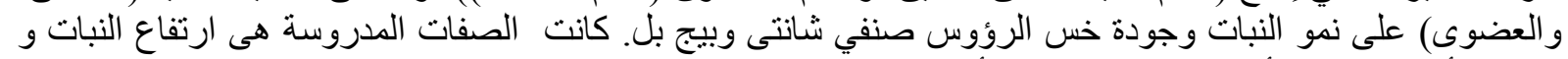

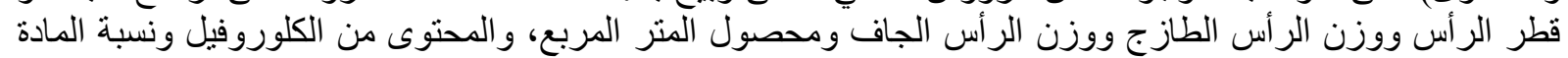

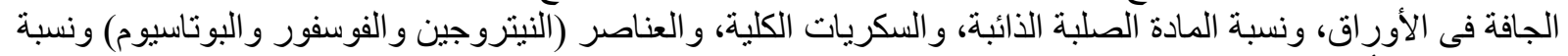

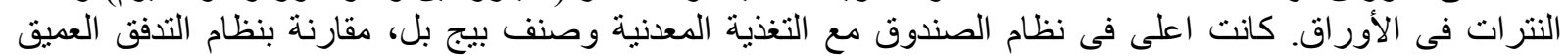

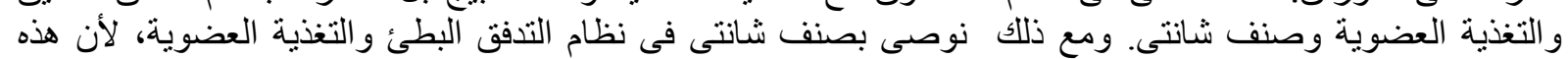

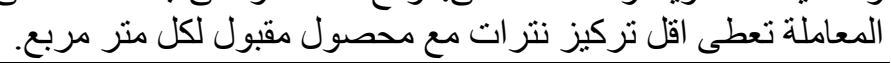

المجلة العلمية لكلية الزراعة - جامعة القاهرة - المجلد (69) العدد الاول (يناير 2018):114-99. 